\title{
POSSIBILITIES OF KALININGRAD CITY COUNCIL'S DEPUTIES FOR DEVELOPMENT OF THE WASTE MANAGEMENT CLUSTER
}

\author{
Sergey Karpushenko \\ Kaliningrad City Council, Russia
}

\begin{abstract}
The formation of an effective household solid waste management system is a very important direction of the activities of Kaliningrad City Council. The function of the City Council is to create mechanisms for solid waste household management for collecting, storage and recycling based on Russian, Kaliningrad Region and Kaliningrad City laws. Results which will be achieved in frame of the international projects between Kalmar City and Kaliningrad City could be a basic for such program realization.
\end{abstract}

\section{KEYWORDS}

Household solid waste management; Legislation for waste management; City target program.

\section{INTRODUCTION}

The formation of an effective household solid waste management system is a very important direction in the activity of Kaliningrad City Council. Nowadays, the situation the sector of City Administration's activities could be illustrated by the following data:

- Kaliningrad population is 423,600 thousand (data for 01.01 .2006 );

- Housing Committee of City Hall provides management with solid waste and (besides other kinds of job) coordination of activity for supporting of good sanitary conditions of city's territory;

- Companies were created to deal with waste collection and transportation (Municipal Company "Chistota", Individual Company "Iljin", "Edelveys" Ltd.); waste transportation is done according to the contracts of housing and other companies; some companies transport their waste by themselves;

- Landfilling of household solid waste is done on the polygon nearby Kosmodemjansky suburb (ground square is 13.5 ha, useful value is $30.0 \mathrm{mln} . \mathrm{m}^{3}$, already disposed for 01.01.2007 about $26.14 \mathrm{~m}^{3}$ );

- Since August 2006, the tariffs for waste transportation and landfilling for public are $15.32 \mathrm{RUR} /$ person/month; norm for waste storage for one inhabitant is 0.133 $\mathrm{m}^{3} / \mathrm{month}\left(1.6 \mathrm{~m}^{3} / \mathrm{yr}\right)$; Table 1 shows the prices for waste transportation services and waste values landfilled during the last five years. 
Table 1. Price, tariff for waste services and values disposed on the city's polygon in 20022006.

\begin{tabular}{cccc}
\hline Year & $\begin{array}{c}\text { Price for waste collecting } \\
\text { and transportation, RUR/m }\end{array}$ & $\begin{array}{c}\text { Tariff for public, } \\
\text { RUR/person/month }\end{array}$ & $\begin{array}{c}\text { Waste values disposed on } \\
\text { the city's polygon, } \\
\text { thousand. } \text { m }^{3}\end{array}$ \\
\hline 2002 & 58.0 & 5.0 & 876.40 \\
\hline 2003 & 88.0 & 9.20 & 934.12 \\
\hline 2004 & 93.60 & 11.70 & 1115.20 \\
\hline 2005 & 104.28 & 13.03 & 1251.55 \\
\hline 2006 & 126.82 & 15.32 & 1399.26 \\
\hline
\end{tabular}

Three large companies (Kaliningradvtorresursy Ltd., Kaliningradvtormet Ltd., Kaliningradvtortsvetmet Ltd.) and several small companies deal with collecting of the secondary resources from waste (paper, cardboard, textile, metals).

Four secondary waste resources collection points work in the city. Data of 2005 showed about 6,000 tons of paper, 0.1 thousand tons of glass, 0.5 thousand tons of textile were collected in Kaliningrad. For comparison: in 199013.274 thousand tons of paper and 1.704 thousand tons of textiles were collected.

\section{LEGISLATION FOR WASTE MANAGEMENT}

Federal and Regional laws and under law normative documents regulate the waste management on the city level. "Temporary rights to manage wastes on the Kaliningrad's territory", "Rules for collecting and utilization of cars and wastes form cars' exploitation" were approved and act in Kaliningrad. Decrees of the Kaliningrad Mayor are belonged to the basic normative documents:

- "On organizing of sanitary conditions of the territories surrounding houses of the City in 2006";

- "On the participation of the municipal body "Kaliningrad City" in supporting sanitary conditions near houses in 2006".

Scheme on the Table 2 demonstrates the modern and complicated structure of the legislative and normative documents of various levels (federal, regional and local). 
Table 2. Structure of the basic legislative and normative documents for waste management approved on the federal, regional and local levels.

\begin{tabular}{|c|c|c|}
\hline Legislative level & Law structure & Description \\
\hline \multirow[t]{2}{*}{ Federal level } & Federal Laws & $\begin{array}{l}\text { - The Constitution of the Russian Federation } \\
\text { - The Housing Code of the Russian Federation } \\
\text { - The Civil Code } \\
\text { - The Land Code } \\
\text { - On the Environment Protection } \\
\text { - On the industrial and housing waste } \\
\text { - Self-management in Russian Federation } \\
\text { - On the fundamentals of Tariffs Regulation of the } \\
\text { Organizations of the Municipal Complex } \\
\text { - On Licensing Separate Kinds of Activities } \\
\text { Population }\end{array}$ \\
\hline & $\begin{array}{l}\text { Decrees of the } \\
\text { Russian } \\
\text { Federation } \\
\text { Government }\end{array}$ & $\begin{array}{l}\text { - About services of companies for managing solid and } \\
\text { liquid household wastes } \\
\text { - About the Federal target program "Waste products" } \\
\text { - About approving of rules on for solid and liquid } \\
\text { household wastes management }\end{array}$ \\
\hline \multirow[b]{2}{*}{ Regional level } & Regional Laws & $\begin{array}{l}\text { - The Statute (Basic Law) of the Kaliningrad Region } \\
\text { - On the Ecological Policy of the Kaliningrad Region } \\
\text { - The Code on the Administrative Trespasses of the } \\
\text { Kaliningrad Region }\end{array}$ \\
\hline & $\begin{array}{l}\text { Decrees of the } \\
\text { Kaliningrad } \\
\text { Region } \\
\text { Government }\end{array}$ & $\begin{array}{l}\text { - About measures on safety neutralization and land } \\
\text { filling of industrial and household wastes on the } \\
\text { territory of the Kaliningrad Region; } \\
\text { - About measures on realization of the Federal target } \\
\text { program for the Kaliningrad Region development for } \\
\text { the period until 2012: } \\
\text { - About approving of "The Territorial complex scheme } \\
\text { of the town-planning development the Kaliningrad } \\
\text { Region" }\end{array}$ \\
\hline \multirow[t]{2}{*}{ Local level } & $\begin{array}{l}\text { Decisions of the } \\
\text { deputies of City } \\
\text { Council }\end{array}$ & $\begin{array}{l}\text { - About approving "Temporary rights for managing } \\
\text { wastes on the territory of the city of Kaliningrad" } \\
\text { - About approving "Rules for collecting and utilization } \\
\text { of cars and wastes form cars' exploitation" } \\
\text { - About approving of reception of polluting substances } \\
\text { of waste waters and discharging by clients in } \\
\text { canalization system of Kaliningrad } \\
\text { - About approving of the Program for recovering } \\
\text { ecological conditions in Kaliningrad in 2006-2008 }\end{array}$ \\
\hline & $\begin{array}{l}\text { Decrees and } \\
\text { orders of the } \\
\text { Kaliningrad City } \\
\text { Hall: }\end{array}$ & $\begin{array}{l}\text { - About measures for providing of the household waste } \\
\text { and large-sized trash land filling from population of } \\
\text { Kaliningrad } \\
\text { - About the order of collecting, storage and recycling of } \\
\text { mercury lamps and waste products } \\
\text { - About rules for designing and approving of norms for } \\
\text { waste producing and limits on their disposal }\end{array}$ \\
\hline
\end{tabular}




\section{FINANCIAL CONDITIONS FOR WASTE MANAGEMENT}

Financial flows in the field of household waste collection, coming out and disposal are organized the following way. Regulation of money flows is started from approving of limits for household wastes accumulation, tariffs for coming out and price for disposal on the polygon by executive authority body. Additionally, the approaches for target financing of non-regular activities for city cleaning (including the household waste transportation on the polygon), the new waste collecting machines purchase and providing preferential payments to local budget are implemented.

On the basic of the Mayor's Decree the mechanism allows to attract the funds from different resources is possible also, i.e. some part of municipal enterprises' profit could be passed to the city's budget for improving sanitary conditions of city territory. Part of this money is spent for housing utility services (including transportation of household waste) as subsidizes for poor people living in the city. Finally, the local legislative and normative documents give an opportunity to finance partly by the funds collecting, storage and utilization of the household waste the target programs with budget participation.

In general, the scheme of money moving could be presented as following: inhabitants, organizations and budget sources pay for services to the financial resources distributor (MUP RIVC "Simplex") through banks and post departments. Then, it transfers payments to participants of activity for waste coming out, storage and utilization (managerial companies, privet and municipal enterprises and organizations).

\section{CONCLUSIONS}

Thus, despite rather wide and well-tried legislative basic for waste collection, transportation and disposal and existence of the appropriate technical basic, the sanitary conditions of city territories are not good so far. The reason of such situation is the absence of the system approach in solving this very actual problem of city's infrastructure. Role of the City Council in solving these questions could be accepted as a main task for choosing strategic directions, legislative and normative principles of the solid waste management in the city. Problems for household solid wastes utilization in Kaliningrad can be explained by the following reasons:

First, there is no such important document as General Scheme for City Cleaning where all legislative, normative, technical and organizational aspects for waste collecting, transportation and utilization process could be written precisely. Analysis the city communal services shows that the best results and the most effective spending of city budget is within the target programs implementation. Now several city programs based on system approach, including General Scheme for City Cleaning are being developed and implemented. Three groups of methods are used: organizational, technological and technical. Organizations are the following: functions of the City Council - development of management mechanisms for waste collection, storage and utilization based on the actual Russian legislation, laws of the Kaliningrad Region and Kaliningrad City.General Scheme for City Cleaning (business project) would include following elements:

- description of the nowadays situation of household solid waste management;

- analysis of problems of the solid waste utilization;

- proposals for optimization and reforming of elements of acting system;

- mechanism for implementation of the project activities and monitoring of their fulfillment based on the normative and legislative documents. 